\title{
Artigo
}

\section{Considerações sobre a ética no candomblé}

\author{
Miriam Rabelo \\ Universidade Federal da Babia, Salvador, BA, Brasil \\ mcmrabelo@uol.com.br
}

RESUMO: A partir da descrição de eventos desenrolados em terreiros de Salvador o texto visa contribuir para uma reflexão acerca do modo próprio do candomblé colocar e resolver questões éticas, formar e oferecer condições para o exercício de uma sensibilidade ética no dia a dia do terreiro. Ao abordar casos relativos à iniciação e formação gradativa de adeptos e ao desenrolar de relações entre pessoas humanas e orixás, pretende-se discutir tanto alguns dos elementos que definem o agir ético no candomblé, quanto caracterizar a montagem ética que sustenta esse agir.

PALAVRAS-CHAVE: prática ética, candomblé, feitura, relações humanos e orixás. 


\section{Introdução}

Um dos poucos autores a endereçar diretamente a questão da ética nas religiões afro-brasileiras, Reginaldo Prandi (1991) viu o candomblé como uma religião aética em que a distinção entre bem e mal é convertida em matéria relativa a cada caso: afinal o que é bom pra mim (nesta situação particular em que me encontro) pode ser mau para você e vice-versa. Desprovido de definições absolutas de bem e mal, ou de um sistema abstrato em que essas definições estejam seguramente assentadas e protegidas (tanto da variabilidade das situações quanto da manipulação de sujeitos interessados), o candomblé, concluiu Prandi, oferece critérios éticos muito frágeis para orientar seus adeptos. Algumas definições clássicas da sociologia da religião ajudaram o autor a compor esse quadro analítico. Diferente das religiões éticas estudadas por Weber, o candomblé parece mais próximo à categoria de religião mágica (voltada não para adoração, mas para a manipulação de forças sagradas) e fortemente ritualística - em que a produção via prática ritual de estados excepcionais, mas claramente descontínuos, conta mais que o cultivo de um tipo contínuo de pessoa moral. Como uma religião ritualística, observou Prandi, o candomblé coloca muitas exigências formais sobre o comportamento do adepto enquanto participante dos ritos, mas o libera para exercer sem constrangimento (e sem julgamento) seus propósitos no mundo; na verdade fornece meios mágicos para fortalecêlo nessa empreitada. Dessa forma, o candomblé é capaz de responder tanto às demandas de indivíduos imersos em um universo cultural pré-ético - que tradicionalmente forneceu seguidores aos cultos afro-brasileiros (supostamente indivíduos para quem os apelos das religiões éticas ainda não fazem sentido), quanto aos anseios de sujeitos afinados com formas de sociabilidade pós-éticas (aqueles para quem apelos éticos universais deixaram de fazer sentido, dando lugar a uma busca por realização espiritual individual, frequentemente de caráter estético e expressivo).

É possível questionar a propriedade desse diagnóstico sociológico, sem questionar os termos sobre os quais está construído - argumentando-se, por exemplo, que existe sim nas religiões de matriz africana uma preocupação com o bem enquanto valor universal, ou defendendo-se uma leitura mais cuidadosa do vasto corpus mítico e ritual destas religiões (leitura que revela os equívocos daqueles que veem o candomblé como religião de total relativismo moral). A meu ver essas objeções são pouco interessantes - não porque estejam erradas acerca dos muitos aspectos que revelam em seu afã de encontrar a Ética (enquanto sistema abstrato de princípios morais) do candomblé, mas porque deixam intacto um quadro 


\section{MIRIAM RABELO. CONSIDERAÇÕES SOBRE A ÉTICA NO CANDOMBLÉ}

analítico que fatalmente conduz a incompreensão da ética que é própria ao candomblé (e que nada tem a ver com esta Ética em maiúsculo).

Assim antes de endereçar os modos de conduta ética que são cultivados no candomblé e que fazem parte da formação dos novos adeptos, vou proceder a um deslocamento mais geral da questão. Isto é, vou abandonar uma definição de ética como sistema abstrato e universal de valores morais, rumo a uma abordagem que a concebe como dimensão integrante de toda prática (da ética enquanto domínio claramente demarcado da vida social, para a ética enquanto um conjunto de problemas ou questões que confrontam qualquer campo de prática). Mais recentemente essa reorientação tem encontrado importantes defensores na antropologia (Lambek, 2010a e 2010b; Laidlaw, 2010, 2014). Central ao projeto desses autores é o argumento segundo o qual:

A ética é parte da condição humana, os seres humanos não podem evitar estar sujeitos à ética, falar e agir com consequências éticas, avaliar suas ações e as de outros, reconhecer e recusar reconhecimento, cuidar e tomar conta, mas também estar cientes do fracasso de fazer isso de modo consistente (Lambek, 2010: 1).

Em sintonia com essa proposta, vou apresentar aqui alguns casos ou situações práticas que envolveram adeptos de terreiros de candomblé em problemas éticos. Espero, ao longo do texto, não apenas deixar mais claro o que quero dizer com isso, como também precisar melhor o modo próprio do candomblé colocar e resolver questões éticas, formar e oferecer condições para o exercício de uma sensibilidade ética no dia a dia do terreiro. Assim pretendo tanto falar de alguns elementos que definem o agir ético nesta religião quanto da montagem ética ${ }^{1}$ que sustenta esse agir: os arranjos discursivos e não discursivos (modos de organização do espaço, das interações e da convivência) que garantem o aprendizado e o fluir da conduta moral no terreiro.

\section{Respondendo a seres em processo de se fazer}

Vou começar resumindo um caso ocorrido em um terreiro angola² de Salvador logo após a iniciação de uma jovem noviça de nome Bárbara. O caso foi acompanhado de perto e relatado em mais detalhe por Aragão (2012).

Bárbara passou por uma situação difícil quando ainda estava cumprindo, no terreiro, o período resguardo que segue à conclusão da feitura. Seu irmão de barco (companheiro de 
iniciação) já havia sido autorizado a voltar para casa, mas ela foi instada a permanecer. A ordem viera diretamente de sua santa ${ }^{3}$ - Bamburucema. Neste período, o kelê de Bamburucema começou a romper; a cada dia um novo fio se partia. Colar grosso de sete fios de contas amarrado rente ao pescoço da iaô em obrigação, o kelê é sinal de sua sujeição ao inquice (orixá, no keto). Caso a noviça (muz̧enza $\left.a^{4}\right)$ já estivesse liberada para sair, a suspeita seria de que quebrara algum resguardo sexual ou alimentar, ofendendo com isso Bamburucema. Mas ela nem saíra do terreiro, nem tivera contato com gente de fora - seu comportamento era monitorado pelas pessoas diretamente responsáveis pela sua feitura, pelos mais velhos da $\operatorname{casa}^{5}$. A mãe de santo perguntava insistentemente à muženza se ela teria feito ou dito alguma coisa para ofender a santa, mas a moça jurava inocência. Como medida de proteção, a mãe de santo enrolou um lenço branco em volta do kelê de Bárbara; mas de nada adiantou. O colar já estava por um fio. Então ela foi aos búzios. Descobriu que a autora do feito era Kayala, inquice que, durante a feitura, já vinha disputando com Bamburucema a cabeça de Bárbara. Deslanchou-se então uma conversa da qual a muzenza conta só ter escutado - sem entender - umas poucas palavras proferidas pela mãe de santo: "a senhora tem que saber esperar". Quando voltou a si - fora tomada por Kayala (a quem a interpelação da mãe de santo, afinal, havia sido dirigida) - disseram-lhe que no kelê de contas vermelhas de Bamburucema, intacto em seu pescoço, havia agora uma firma de Kayala. Depois a mãe de santo explicou que negociara com a santa. Kayala havia concordado em deixar Bárbara em paz; a mãe de santo, por sua vez, além de adicionar uma firma sua no kelê da muženz̧a, prometera que também ela, Kayala, comeria (receberia oferenda) a cada nova obrigação de Bárbara.

Temos aqui um breve retrato dos percalços de uma feitura. Como se sabe, vários tipos de vínculos conectam os seres que fazem parte do mundo do candomblé. Entre estes vínculos, estão aqueles de que é feita a pessoa, entidade composta, mas cuja composição precisa ser ativada, passo a passo, no terreiro. A feitura dá início a esse processo, fazendo nascer no terreiro, um para o outro, um muzenza e um inquice que é o dono de sua cabeça ${ }^{6}$. É seguida por uma série de procedimentos rituais (conhecidos como obrigações) que gradativamente assenta no corpo do noviço (e no terreiro) mais uma das entidades a que ele está vinculado. O feito da feitura (e das obrigações subsequentes) é encaminhar seres relacionados em uma trajetória, oferecer condições para que seus laços sejam desenvolvidos e para que cada um (tanto a pessoa quanto o santo que é feito com ela) possa emergir como um ser mais completo e diferenciado justamente pelo adensamento de suas relações. Como Bastide (1973) observou, o universo do candomblé é a um só tempo relacional e inacabado - sempre em processo de se fazer. 
A feitura abarca um conjunto complexo de procedimentos que precisam ser bem conhecidos por aqueles que irão conduzi-la. Requer atenção para os detalhes, para as muitas variações nos modos de fazer, para as inúmeras exceções à regra. Também requer maleabilidade, criatividade mesmo, pois cada caso é um caso, e pais e mães de santo precisam estar preparados para eventualidades, para soluções e arranjos de última hora. Mas a questão central que permeia a história acima é menos uma questão de conhecimento do saber necessário para se variar com base no procedimento padrão - que uma questão de "responsividade" - de sensibilidade para responder aos apelos de seres que demandam reconhecimento, mas que ainda existem de modo fraco, que estão em processo de se fazer. Esta, sugiro, é a questão ética da feitura. Endereçá-la é estar preparado para responder ao apelo de outros, mas no candomblé responder já é engajar-se com a existência de quem apela, é contribuir para a sua instauração. Emprego aqui o termo no sentido proposto por Souriau (1943) e depois retomado por Latour (2012) para quem o inacabamento existencial de todas as coisas exige que elas sejam instauradas - isto é, conduzidas em uma trajetória rumo à realização. Há pelo menos três pontos de aproximação entre os conceitos de instauração e feitura: a ideia de que a existência se declina em graus ou intensidades diferentes; de que depende sempre de trabalho, de investimento e frequentemente da colaboração de muitos; e, por fim, a realização de que, no final das contas, nossos investimentos podem falhar.

Em O Candomblé da Babia, Bastide (2001) faz uma observação chave para entendermos a aproximação ora proposta entre feitura e instauração. Na cosmologia africana, ele explica, ser equivale a poder e, como tal, comporta sempre gradações: é-se mais ou menos. E uma vez que todo poder vem dos orixás, cada vínculo firmado e renovado com os deuses resulta em incremento de ser. Para Bastide, o processo incremental de ser/poder que é posto em movimento no candomblé comporta sempre uma dimensão ética: quanto mais a pessoa é (ou quanto mais potência agrega), mais é cercada de obrigações: mais encargos tem, mais peso carrega de cadeias rituais, ou, poderíamos ainda dizer, mais responsável se torna pela feitura de outros. Quanto mais negligencia suas obrigações, mais sua existência se enfraquece.

Têm-se aqui os dois primeiros sentidos da ideia de instauração. Em um mundo de gradações, é possível se existir de modo fraco ou forte, é possível que a existência se alargue ou se encolha, a depender da força/potência acumulada. E quanto mais força, mais obrigações, mais encargos ou compromisso com a existência de outros. Por isso cabe principalmente aos pais e mães de santo encaminhar os processos de feitura daqueles que chegam aos seus terreiros, não só de seus filhos humanos, mas também das entidades que a 
eles se vinculam - variantes únicos dos orixás gerais, estas também ingressam no terreiro de modo ainda fraco ou incompleto. Pode-se dizer que o fato de que no candomblé as pessoas humanas e as entidades sagradas precisam ser feitas torna os adeptos particularmente atentos e explicitamente comprometidos com a instauração dos seres que ingressam no terreiro.

Para Souriau (1943), toda instauração comporta risco - não há garantia de que o processo será bem sucedido. É possível se ler a feitura em uma chave que minimiza o trabalho de instauração que ela exige e, portanto, o risco que comporta. Nesta chave, assumese que embora requeira trabalho por parte de seus oficiantes, a feitura segue um caminho mais ou menos linear: uma vez que o orixá, dono da cabeça, responde nos búzios (revela sua identidade no processo divinatório), então cabe à mãe ou pai de santo seguir os passos costumeiros para a iniciação dos filhos deste orixá. Frequentemente essa é a perspectiva do observador de fora: há muitos ritos na feitura, mas, no geral, poucos riscos, quando o procedimento padrão é bem conhecido.

A perspectiva da gente de candomblé é outra, principalmente quando se tratam dos mais velhos no santo (aqueles com mais tempo de iniciação'): sempre que tem noviço recolhido na casa, o clima é de apreensão e cuidado redobrado. Afinal, durante a feitura, o corpo do noviço está aberto: preparado para receber o santo, mas também vulnerável a todo tipo de influência. O orixá está próximo, mas muitas forças são convocadas para que a relação entre ele e sua filha humana aconteça no terreiro, outras tantas são potencialmente atraídas no processo - e é preciso lidar com elas. E embora os procedimentos da feitura obedeçam a uma configuração prévia, revelada no jogo, esta configuração só se confirma mesmo quando a feitura é deslanchada: até então o que era dado como certo, pode ainda se revelar diferente. Há casos e casos: dois orixás podem estar disputando a cabeça do noviço, um orixá de herança ${ }^{8}$ pode se revelar quando ele estiver recolhido, demandando atenção, seu orixá de frente pode ter permanecido oculto e só então resolver se mostrar. Recorre-se ao jogo, sempre que necessário. Arriam-se oferendas para agradar (e talvez também afastar) os visitantes inesperados. Negociações são postas em marcha. E, no final de tudo, paira ainda o receio de que o santo, criado no roncó (quarto de iniciação) junto com sua filha humana, por alguma razão se recuse a proferir seu nome em público, na cerimônia que marca sua apresentação formal à comunidade de fora e que confirma o sucesso da feitura.

A feitura ensina que num terreiro é preciso considerar a presença de seres cuja voz pode inicialmente ser difícil de distinguir, seres que existem de modo fraco ou incompleto, ainda em vias de aceder a uma existência plena. Há sempre muitas entidades demandando 


\section{MIRIAM RABELO. CONSIDERAÇÕES SOBRE A ÉTICA NO CANDOMBLÉ}

participar da vida de uma casa de candomblé (não só orixás, mas também exus, caboclos, eguns') e, uma vez admitidas, elas precisam ser cuidadas e, pelo menos em parte, atendidas em suas exigências. Pode ser difícil lidar com os recém-admitidos - e os adeptos (sobretudo as mães e pais de santo) estão bem cientes desse fato. No caso narrado acima, Kayala disputou com Bamburucema a cabeça da noviça e ameaçou o sucesso da feitura. Mas enquanto esta última já havia "nascido" no terreiro - já fora assentada e alimentada em ritos internos da casa e já se fizera visível no corpo de Bárbara, sua presença testemunhada tanto pelos de dentro quanto por visitantes de fora - Kayala se insinuava via um apelo ainda difícil de reconhecer. Quando a mãe de santo respondeu a Kayala - "a senhora precisa ter paciência" - não apenas reconheceu sua presença, como agregou força ou intensidade a sua existência. E, de maneira criativa, empregou os recursos técnicos do candomblé para instaurar Kayala no seu terreiro - colocou uma firma de Kayala no kelê de Bamburucema e prometeu-lhe uma festa ao final do período de cada nova obrigação de Bárbara. Assumiu o trabalho que enseja o ingresso de cada nova entidade ao terreiro.

Um terreiro precisa formar pessoas que sejam não só sensíveis aos apelos daqueles que chegam como também preparadas para assumir as consequências de sua resposta a estes apelos. Quando é noviça ainda sem obrigação de três anos, a pessoa depende de muitos outros (sua mãe ou pai de santo, mãe e pai pequenos, seus mais velhos) para ser encaminhada em sua gradual composição, existe quase como uma extensão desses outros, de sua força e habilidade para conectar. Assim é a muzenza de Bamburucema - dependente da mãe de santo para se fazer junto com entidades que ela ainda mal sabe reconhecer. À medida que passa pelas etapas formativas da trajetória de uma filha de santo, ela se torna mais autônoma - o que no candomblé quer dizer que ela vem a ser foco para o encaminhamento de novas relações, para a instauração de novos seres.

A formação da filha de santo no candomblé é um processo longo: como já observei, requer muito trabalho por parte de seus mais velhos (adeptos com mais tempo de iniciação), mas também requer dela um trabalho sobre si - sobre seu corpo, suas condutas e disposições - para se converter, gradativamente, em uma pessoa mais completa (mais relacionada e mais autônoma). Para alguns autores é justamente isso que define a ética: as práticas pelas quais as pessoas buscam se transformar em consonância com os ideais de virtude, felicidade ou verdade definidos pela tradição a que pertencem. Na filosofia essa concepção é conhecida como ética da virtude. Enquanto as abordagens rivais do utilitarismo e da deontologia situam a ética no plano da conduta - seja enquanto prática orientada por princípios, seja enquanto 
agir que almeja o bem - a ética da virtude a situa no campo do ser - no processo mesmo de autoconstituição dos sujeitos. Aparentemente teríamos aqui uma concepção de ética bastante afinada com o mundo do candomblé - mundo em que a constituição das pessoas é matéria de intenso investimento tanto por parte de mães e pais de santo (e de toda comunidade do terreiro), quanto por parte dos próprios sujeitos em processo de se fazer.

Em seus escritos sobre o tema, o filósofo americano John Dewey expressou algumas reservas frente à ética da virtude e vou recuperar um pouco seu argumento (com a ajuda de Pappas, 2008) porque me parece bem apropriado para iluminar a particularidade do candomblé. Conforme Dewey (1980) a ética da virtude compartilhava com outras abordagens (a utilitarista, por exemplo) de uma visão possessiva ou aquisitiva da moralidade em que o agir ético ou a autorrealização são concebidos em termos da obtenção de algo (virtude, felicidade, etc.) para o eu (self). Nesta concepção, observou Dewey, o tempo que domina o agir ético é o futuro: tem-se a ideia de que o eu confronta sua conduta de um ponto de vista externo, tomando-a como meio para obter ou tornar-se algo. Para o filósofo, aí residia seu equívoco, pois apenas por um decreto artificial podemos separar o eu de seu comportamento. A alternativa proposta por Dewey consistia em pensar a ética segundo um modelo estético. Para ele isso significava tomar a experiência moral como uma experiência de consumação, vivida desde dentro por um self que não se distingue de sua atividade e que se transforma com ela.

Quero propor aqui que o candomblé (ou a montagem ética do candomblé) coloca certas barreiras ao agir ético orientado dominantemente pela perspectiva do vir a ser um tipo de pessoa, guiado exclusivamente pelo futuro. E essas barreiras têm a ver com uma definição marcadamente estética da ética - uma forte estetização dos lugares intermediários pelos quais passa a pessoa em caminho para completar-se ou para existir de modo mais bem acabado. Explico. O terreiro é um espaço fortemente hierárquico. Neste espaço, a posição de noviça ocupada por Bárbara é definida por uma combinação de ignorância (ou não conhecimento) e forte submissão. Não tem acesso à boa parte dos procedimentos rituais realizados no terreiro (esse acesso lhe é expressamente vetado) e, à exceção dos seus irmãos de iniciação e dos aspirantes à iniciação, todo mundo manda nela. Na medida em que venha a realizar as obrigações que marcam os anos de feitura, Bárbara subirá na hierarquia da casa, terá acesso a conhecimentos tidos como de fundamento, e poderá ocupar posição de mando. Mas submeter-se aos outros e conformar-se com a situação de ignorância que lhe é destinada não são apenas uma etapa inicial de um processo de conhecimento e autonomia crescentes, ou melhor, não são simplesmente meios para Bárbara se tornar uma pessoa mais completa. São 


\section{MIRIAM RABELO. CONSIDERAÇÕES SOBRE A ÉTICA NO CANDOMBLÉ}

definidores de uma existênci ${ }^{10}$ que precisa ser vivida intensamente por ela e que é fortemente exibida (ritualizada) no seu corpo e no terreiro. A estetização deste modo de ser é bem visível na indumentária da noviça, no seu corpo curvado, seus gestos de humildade - é reforçada, como veremos adiante, por uma complexa etiqueta.

\section{Uma ética da composição}

Presenciei certa feita a conversa entre dois jovens que em breve pagariam sua obrigação de sete anos (ritos pelos quais um filho de santo se torna um adepto sênior ou ebomi), ocasião em que também receberiam o cargo de pais de santo, sendo-lhes no futuro permitido abrir seus próprios terreiros. Ambos tinham essa intenção e estavam dedicando-se com afinco ao aprendizado, já assistindo a sua mãe de santo em várias tarefas importantes. Também procuravam ampliar seu conhecimento frequentando festas em outras casas, fortalecendo contatos interterreiros e recorrendo à literatura escrita sobre a religião.

Quando entrei no barracão, a conversa já tinha começado. Só os dois estavam lá, já prontos, para a celebração que em breve teria início. Juntei-me a eles. A conversa, que inicialmente tratara do caso de um rapaz que fora iniciado em um terreiro da nação keto apesar de ser filho de Tempo, orixá angola que não tem correspondente no keto ${ }^{11}$, agora girava em torno de uma situação hipotética: se isso acontecesse no futuro terreiro deles o que fariam?

- Se fosse na minha casa, eu não faria (o santo), na hora que visse que era Tempo, mandava para uma casa angola que eu conhecesse.

- Pois eu recolhia na minha casa. - disse o outro - Qual o problema disso?

- Mas se eu não sei fazer no angola, como é que eu posso assumir essa responsabilidade? O que eu sei eu aprendi com minha mãe [no keto], sei fazer no jeito dela. Não ia saber cuidar de uma pessoa de Tempo.

- É só chamar alguém que sabe pra ajudar. É isso que eu ia fazer. Se a pessoa veio pra minha casa, então eu vou cuidar.

- Eu explicava pra ela, "olhe seu santo é angola, aqui é uma casa keto, eu vou mandar você para tal ou qual casa, que lá é angola”. 
Delineava-se assim uma polarização interessante da qual, tudo indicava, resultariam estilos bem diferentes de conduzir o candomblé. Edson, cauteloso e aparentemente mais atento a suas limitações, não arriscaria, no seu terreiro, levar adiante uma feitura que requeresse procedimentos que ele não dominava; Lula, mais confiante, não teria problema em fazê-lo, afinal sempre poderia recorrer à ajuda de especialistas mais versados que ele nos modos do angola. Fortemente apegado à tradição da casa onde foi iniciado, Edson agiria exclusivamente no âmbito daquilo que aprendeu com sua mãe de santo. Talvez menos apegado, Lula estaria mais disposto a explorar os limites da tradição.

Mais um passo nesse raciocínio e concluímos que enquanto um toma decisões com base em considerações morais, o outro é guiado prioritariamente pelo interesse próprio. $\mathrm{O}$ desenrolar da conversa veio a mostrar que o contraste entre ação instrumental e ação valorativa não era apropriado e talvez fosse um contraste grosseiro demais para iluminar a questão.

- Veja bem - argumentou Lula lá pras tantas - se a pessoa me procurou e pediu a minha ajuda, se o santo a trouxe aqui, ele escolheu onde quer ficar. E se foi escolha do orixá, então eu tenho que respeitar, meu dever é cuidar.

Duas semanas depois, um jovem tata (pai de santo no angola) veio dar uma palestra no terreiro. $\mathrm{O}$ evento era parte de um ciclo de encontros promovidos por um grupo de adeptos (com pretensões a criar uma associação) para aprofundar o conhecimento da religião. Depois de falar sobre o candomblé angola, o pai de santo respondeu a algumas questões. Não lembro bem se a pergunta partiu de Edson ou de Lula, mas visava reviver o debate que os consumira anteriormente.

- Você faz em seu terreiro um orixá de outra nação que não a sua?

A resposta do tata - reforçada por duas ebomis bem antigas do terreiro - foi a seguinte:

- Se o orixá veio para minha casa, ele escolheu ser feito lá.

- Mas como é que você vai fazer? - insistiu Edson, aparentemente menos interessado em defender sua posição, enfraquecida com a resposta do tata, que em aprender algo novo sobre o candomblé.

O tata, então, recorreu a uma distinção interessante:

- Se um orixá keto vai ser feito em minha casa e a casa é angola, então todos, incluindo o orixá, terão que observar o rito público angola. Essa é 
uma satisfação que se dá para os de fora. Agora lá dentro, você vai ter que contar com a ajuda de alguém que saiba conduzir a feitura na nação do orixá. Você vai ter que chamar alguém do keto.

Gostaria de destacar alguns elementos dessas duas situações que a meu ver são bastante esclarecedores quanto ao tipo de questão ética que é relevante no candomblé e à maneira pela qual essa questão é, em geral, endereçada, no dia a dia dos terreiros.

Em termos mais amplos, o problema central aqui gira em torno do modo correto de se fazer pessoas e orixás - de quem está autorizado para fazê-lo e de onde provém a sua autoridade para tal. Embora ser pai ou mãe de santo seja exigência mínima para que se possa conduzir a feitura de outros - só pode recolher iaô quem já passou pelo longo e árduo processo de feitura no candomblé, já acompanhou a feitura de outros e foi escolhido pelo orixá para assumir esse papel - outras considerações estão em jogo que dizem respeito à particularidade da situação. Posso ou devo fazer o santo de alguém se este santo não pertence à nação de meu terreiro e se eu não domino os procedimentos da feitura na sua nação? Devo acolher a pessoa que me pede ajuda nessas circunstâncias ou me negar a fazê-lo? Decido com base em minha competência ou minha obrigação de cuidar? Ou ainda: sou mesmo o principal responsável pelo desdobrar dessa situação?

Do ponto de vista de uma antropologia da ética, o que é mais interessante neste caso não são as regras que regulam a feitura e suas instâncias particulares, mas a situação que faz hesitar os atores, que sugere para alguns deles ao menos que é preciso cautela, que talvez a resposta padrão não seja a melhor aqui ou que é preciso ponderar mais antes de levar adiante o processo. Interessa entender o que transforma a situação em problema ético - e por problema ético não quero dizer simplesmente o que demanda a aplicação de regras morais conhecidas, mas o que produz incerteza quanto aos critérios mesmos a partir dos quais julgar e responder a situação.

Por um lado parece se sobressair a exigência de seguir a tradição - que sabemos jogar um papel importante tanto na dinâmica interna dos terreiros quanto no modo como o candomblé é apresentado por seus porta-vozes autorizados enquanto uma religião fiel à sua origem africana. Mas é importante notar que quando Edson invoca a tradição, ele não está se referindo a um conjunto de princípios reguladores externos, mas a um modo de fazer aprendido em contextos concretos via observação e participação na atividade dos mais velhos. A tradição a que ele se apega são procedimentos que aprendeu com sua mãe de santo, nos quais ele tem confiança e que ele sabe serem propícios para encaminhar algumas 
situações de feitura a um desfecho feliz. Podemos dizer que Edson está menos preocupado com a fidelidade a princípios que com a falta de habilidade para presidir a feitura do orixá angola. O problema que lhe confronta são os limites do seu conhecimento. Mesmo para ele não se trata exatamente de escolher entre ser ou não fiel à tradição. Ou entre fidelidade e traição. A escolha é mais humilde, menos radical: fazer apenas o que ele sabe fazer bem ou assumir o risco de não saber.

Por outro lado, tem-se o apelo das entidades. É em torno deste ponto que gira o argumento de Lula (depois reforçado pelo tata) - um argumento que desloca de modo interessante o problema ético, que o transforma em uma questão de responsividade a outros, cuja vontade precisa ser reconhecida (vimos isso no caso anterior). Se no primeiro caso a virtude é definida pelo compromisso com a herança legada do passado, agora ela é definida pela prontidão para reconhecer e responder ao apelo dos orixás ${ }^{12}$. A possibilidade de o orixá angola ter escolhido a casa keto para sua feitura minimiza o valor de considerações acerca da competência do pai de santo ou da sua fidelidade à tradição - pelo menos faz hesitar os que se guiam por essas considerações.

Embora o tata seja bastante categórico em sua resposta, ele bem sabe que antes de qualquer coisa é preciso confirmar a vontade do orixá. Ele vai recorrer ao jogo. Mas também vai perscrutar a situação - não apenas observar com atenção o desenrolar dos eventos, mas interferir ativamente neste desenrolar para convidar ou provocar o santo a se mostrar: acender uma vela, arriar uma oferenda, sacrificar um galo, convocar os ogãs ${ }^{13}$ para entoarem nos atabaques os toques do orixá. Ele vai procurar intensificar o apelo das entidades com os meios técnicos que tem a sua disposição - o vasto estoque de tecnologias rituais do candomblé.

Que consequências tem isso para a conduta ética? Para responder essa questão vejamos o sentido que assume a técnica no candomblé. Em linhas gerais, diria que três aspectos se sobressaem. Primeiro, o emprego da técnica (não só no candomblé) é sempre orientado pela situação sobre a qual se quer interferir - exige atenção às características próprias de cada caso. Segundo, é, em geral, um exercício de criatividade - no dia a dia dos terreiros é preciso atuar com os materiais e os recursos de que se pode dispor e com as possibilidades que a situação oferece - recorre-se a manipulações diversas e negocia-se com as entidades que demandam algum tipo de retorno de seus parceiros humanos. E, por fim, essa dependência na técnica fomenta a responsabilidade ${ }^{14}$ : afinal nossos investimentos podem falhar, as técnicas que empregamos podem não produzir o resultado esperado, novas investidas podem ser necessárias. 
Quanto mais o praticante experiente interfere para intensificar os apelos das entidades, mais ele se torna sensível a estes apelos. Isto é, mais preparado ele se torna para reconhecer diferenças e sutilezas nesses apelos (ele contribui afinal para sua instauração), e mais apto está para responder. Ou ainda: mais ele se sente instado a considerar seriamente as particularidades da situação, afinal se na situação se delineia - ainda que fraca ou indistintamente de início - o apelo do orixá, então é preciso estar mais atento a ela e comprometido com o seu desenrolar. Além disso, se o orixá emerge como integrante pleno da situação, então não cabe exclusivamente ao pai ou mãe de santo decidir. A produção de pessoas sensíveis aos apelos de entidades ainda em vias de se fazer e a concomitante multiplicação das agências envolvidas no desdobrar dos eventos (dimensões importantes da vida no candomblé) têm como consequência também a distribuição da responsabilidade. A fala do tata, confirmada pelas ebomis, não só renova a necessidade de que, frente a problemas éticos, é preciso tratar cada situação como única, mas também lembra que mães e pais de santo não são o centro da ação, que o poder de decisão não repousa exclusivamente em suas mãos e que nem tudo o que acontece no terreiro depende deles. Lembra que o agenciamento de outros, mais fortes, mais experientes, mais sábios, pode ser uma alternativa necessária em um processo de feitura.

No candomblé cultiva-se uma ética que se volta para as situações procurando nelas a chave para a boa conduta. Uma ética que é menos um sistema de princípios gerais que uma etiqueta. O comentário final do pai de santo angola retrata esse fato: na feitura do orixá keto no terreiro angola tem-se um rito público que dá satisfação aos visitantes - e no qual se exibe a identidade angola da casa - e um rito fechado que dá satisfação ao orixá - e que segue o preceito de sua nação.

Dar satisfação é uma noção corrente nos terreiros (e também fora deles): indica a necessidade de que a pessoa se apresente de uma forma que seja compreensível ou aceitável a outros que, em qualquer momento, estejam na posição de esperar dela consideração e respeito - orixás, adeptos mais velhos, autoridades de outros terreiros, visitantes de fora que vêm assistir às festas - que ela seja capaz de satisfazer suas justas demandas. Para os seus críticos - aqueles que dizem não ter que dar satisfação a ninguém - trata-se de uma obrigação que enfatiza a opinião dos outros no lugar da convicção própria ou do compromisso verdadeiro, que se guia pelas aparências. No candomblé leva-se muito a sério a obrigação de dar satisfação aos outros, assim como também se levam muito a sério as aparências: nos dois casos a questão não é o cultivo da artificialidade ou da superficialidade (ambos atributos frequentemente associados à etiqueta), mas a valorização dos vínculos que definem a pessoa (ou o grupo). 
Mas o comentário do tata chama atenção para o fato de que muitas vezes é preciso dar respostas diferentes aos diferentes outros que definem e fortalecem um terreiro: é preciso, por um lado, dar satisfação aos de fora, àqueles que vêm assistir às festas públicas do terreiro, admirar e se beneficiar do axé da casa, muitos dos quais, gente de outros terreiros; por outro lado, é preciso dar satisfação aos santos mesmos, empregar os procedimentos condizentes com sua natureza, fazer as coisas no modo de sua nação. Aqui entra a etiqueta: na festa, feita para dar satisfação aos de fora, domina o cerimonial angola; no roncó, a história é outra. Os procedimentos decisivos ocorrem aí, mas isso não quer dizer que a festa engana os de fora: quer dizer que exibe uma parte apenas, mas bastante verdadeira, da vida do terreiro: sua feição pública e acessível a todos.

Vale notar que temos aqui um modo próprio de composição regido pela ética - ou talvez devêssemos falar de uma ética de composição - em que a casa agrega elementos novos no processo mesmo de responder (dar satisfação) aos outros que a ela se vinculam. Neste processo adicionam-se elementos do rito keto na casa angola em reposta ao santo keto que aí ingressa, mas, a cada nova adição, produz-se também uma nova diferença de contexto no caso hipotético descrito acima, não só entre o contexto público e o contexto fechado do roncó (um regido pelo angola, o outro pelo keto), como também, no rito público, entre o tom geral da cerimônia (angola) e o momento em que se toca (no keto) para o santo dar o rum (dançar). Esse modo de composição conta uma história - de escolhas e afinidades dos orixás, de complexos enredos de feitura, de obrigações herdadas e contraídas, de colaboração entre especialistas de diferentes nações na feitura de um santo e/ou na abertura de uma casa ${ }^{15}$. Também multiplica as diferenças - uma casa angola, por isso mesmo, nunca será idêntica às outras da mesma nação ${ }^{16}$ - ao tempo em que abre caminho para novas aproximações e adições.

Como já notei acima, uma complexa etiqueta regula essa dinâmica. Recorro a mais um exemplo para melhor caracterizar a etiqueta do candomblé.

\section{A ética como etiqueta}

Há alguns anos, um evento crítico se desenrolou em um terreiro tradicional da Bahia que ameaçou abalar o sempre tenso equilíbrio de poder reinante em casas muito antigas, que contam com adeptos de muitas gerações de feitura, nem todos feitos pela pessoa que ora 
ocupa a liderança da casa. A mãe de santo entregou um cargo para uma ebomi do terreiro. Um grupo mais antigo da casa discordou da escolha - argumentando que, pelas regras de senioridade, outras ebomis bem mais velhas e experientes deveriam ter tido precedência. Para este grupo, a mãe de santo desrespeitara o costume. Como consequência, a nomeação passou a ser objeto de forte crítica em alguns círculos. Uma reunião fechada foi convocada diretamente pelo Ogun de uma ebomi insatisfeita, para discutir o assunto. Uma noite, esse mesmo santo bateu enfurecido na porta da mãe de santo. Ela foi prevenida, mas teve que atender - afinal era o Ogun de uma ebomi antiga da casa, não podia tratar como se fosse o santo de uma iaô (noviça). Ogun entrou com seu porte de guerreiro. Questionou a conduta da mãe de santo com base na tradição da casa - nunca se vira uma escolha dessas na história do terreiro.

- Pois é, meu velho - teria dito ela - mas eu também nunca vi orixá convocar reunião...

Vários aspectos tornam esse caso particularmente interessante para um estudioso do candomblé - ele revela as rixas que permeiam o cotidiano de terreiros grandes e antigos, o apelo à tradição como meio para se resolver e ganhar disputas, a habilidade - astúcia mesmo da mãe de santo para lidar com conflitos. Queria aqui destacar ainda outro aspecto: a etiqueta que rege a negociação entre as partes e seus efeitos na dinâmica relacional do terreiro.

Primeiro, temos a etiqueta que opera entre adeptos situados diferentemente na hierarquia do terreiro. Como já observei, essa requer, da parte dos noviços, a exibição de sua sujeição aos mais velhos: são fortemente ritualizados os modos pelos quais abiãs (adeptos ainda não iniciados) e iaôs se dirigem às autoridades da casa. As diferenças hierárquicas entre as pessoas humanas se estendem, embora modificadas, para os seus orixás. Um orixá, é claro, sempre recebe um tratamento diferente daquele que é dispensado a sua filha humana - afinal é uma divindade. Mas o santo de uma iaô está, como ela, ainda no início de um longo trajeto de feitura e cabe aos mais velhos conduzir - e instruir - tanto a iaô quanto o santo nesse trajeto. Em outras palavras, também os orixás estão sujeitos - ainda que de modo diferente dos humanos - à etiqueta que rege as relações hierárquicas no terreiro. A mãe de santo do caso relatado acima recebe o Ogun que bate à sua porta - não simplesmente porque é orixá, mas porque é o orixá de uma ebomi antiga da casa. Esse ponto foi bastante frisado pela pessoa que me relatou o evento. Se fosse o santo de uma iaô, ela nem se daria ao trabalho de receber. Se fosse a ebomi em pessoa que batesse à sua porta com tamanha insistência, provavelmente ela tomaria como uma ofensa. Mas sendo o orixá da ebomi, ela é compelida, pela etiqueta, a dialogar - a ouvir o que ele tem a dizer e a responder. 
A vinda do orixá certamente transforma a situação, mas não o faz de maneira radical - invertendo, por exemplo, a direção do poder (fazendo com que a mãe de santo, de senhora da situação, passe à subordinada). Na verdade, ao solicitar da mãe de santo que observe uma etiqueta própria às divindades, desacelera o ritmo do conflito. Introduz uma pausa. A mãe de santo conversa com Ogun, santo que, pelos muitos anos de feitura no terreiro, já é bem conhecido seu. Trata-o como "meu velho".

Em outra situação, já relatada por mim (Rabelo, 2014), um iaô que deixara o seu terreiro e levara consigo o assentamento do seu santo, voltou tempos depois pedindo perdão: queria ser readmitido à casa onde fora feito. Chorou agarrado à mãe de santo e logo foi tomado por Obaluaê, seu santo de cabeça. O Obaluaê do iâ̂ prostrou-se no chão, aos pés da mãe de santo; esta pousou os dedos em seus ombros e nuca, e com este gesto ele se ergueu. De joelhos, aguardou que ela lhe concedesse a bênção. A situação terminou num abraço.

Não há dúvida de que chegada do orixá provocou um reordenamento na situação: se inicialmente era o filho arrependido que esperava o perdão da mãe de santo, agora era o santo mesmo quem pedia desculpas e exibia sua submissão. Ao tomar o corpo de seu filho, Obaluaê produziu uma pausa no desenrolar de eventos que poderiam ter resultado na expulsão definitiva do iaô do terreiro. Vale notar que não havia nenhuma garantia de que efeito final dessa mediação fosse favorável ao iaô: a mãe de santo poderia ter recusado o seu pedido de reingresso mesmo assim. Entretanto Obaluaê mudou o tom do encontro, exigiu da mãe de santo outros modos.

Meses depois, o iaô aprontou de novo e afastou-se de vez do terreiro. Ele e a mãe de santo ficaram um bom tempo sem se encontrar até que ela o viu no enterro de um conhecido em comum. Quando notou que ele se aproximava, foi logo se afastando. Pouco depois entrou no carro para partir. "Se ele vier falar comigo, vai virar no santo, e eu não quero que isso aconteça”, disse, já prevendo e evitando a mudança de tom que a chegada do orixá provocaria.

Temos aqui um mundo onde atuam e frequentemente se sucedem agências muito diferentes, onde a ação e a responsabilidade são distribuídas e onde domina uma intrincada etiqueta. A etiqueta no candomblé é de fato bastante elaborada - uma complexa economia de gestos, posturas, vestimentas e adereços marca a posição de cada um no terreiro e regula as relações entre seus habitantes, não só entre adeptos humanos e entre as entidades como também entre estas últimas e os primeiros. A etiqueta do candomblé marca diferenças entre as pessoas (de acordo com sua posição na hierarquia religiosa ou, como sugere Bastide, 2001, 


\section{MIRIAM RABELO. CONSIDERAÇÕES SOBRE A ÉTICA NO CANDOMBLÉ}

em uma escala de existência), entre as entidades com quem se interage e entre as situações de interação e, para complicar, também relaciona esses marcadores: como vimos acima, em muitos casos, para saber como responder a um orixá, importa também saber quem é seu filho (se é sênior - ebomi - ou não, por exemplo). Por vezes, a etiqueta confunde os novatos e leva os observadores à conclusão de que há um excesso de formalismo nos terreiros. Embora haja muitas diferenças nos estilos das casas (algumas mais, outras menos formais), é importante não confundir etiqueta com formalismo.

No candomblé a etiqueta remete ao vínculo estreito entre ética e estética - ela dá máxima visibilidade às diferenças e dependências entre os seres, tornando-as matéria de fruição intensa. Treina atenção para essas diferenças e oferece meios para administrálas. Na medida em que demanda atenção a mudanças sutis nas situações de interlocução (a substituição do filho, humano pelo seu orixá, por exemplo), e força uma reorganização da conduta em função dessas mudanças, tem como efeito produzir pequenas pausas no curso dos eventos, retardar decisões, tornar mais longo ou mais difícil o percurso entre uma ocorrência qualquer e a resposta que se dá a ela. Nesse sentido realiza também um trabalho ético importante: parafraseando Stengers (2005b), é possível dizer que, ao retardar a ação (ao marcar a entrada e exigir o reconhecimento de uma nova voz), a etiqueta faz emergir uma perspectiva ligeiramente diferente do problema e das situações a enfrentar. Num mundo em que muitas entidades aguardam ser instauradas e em que a trajetória de instauração dos seres é matéria de preocupação explícita e investimento contínuo, este trabalho é muito importante para a convivência.

\section{Conclusão}

Argumentei neste texto que, devido a um arranjo particular de pessoas, coisas e espaços e de formas de interação, a ética do candomblé, no lugar de promover distinções absolutas e princípios inarredáveis, acentua as particularidades e nuances das situações. Valoriza a sensibilidade aos diferentes apelos que ressoam no terreiro e, ao exigir que as situações sejam vividas intensamente, ao estetizá-las ao máximo, coloca freios às tentativas de descartá-las muito rapidamente em favor de um futuro predeterminado. Aposta nas intervenções ou manipulações técnicas. Fomenta um senso de que as coisas podem a qualquer momento dar errado - afinal nenhuma manipulação oferece garantias absolutas - e, assim fazendo, produz 
responsabilidade. Mas, ao mesmo tempo, contribui para a realização de que ninguém ocupa o centro das decisões. Descentra a ação e distribui a responsabilidade.

Para finalizar gostaria de ressaltar um último ponto. No candomblé a ética, longe de ser um assunto exclusivamente humano, diz respeito às possibilidades de convivência entre seres diferentes e em processo de se fazer. Seres cuja existência depende de sua força para conectar ou de sua chance de contar com a força de outros, aplicada a seu favor - seres que apelam, respondem e negociam - que também agem eticamente - mas que frequentemente precisam de pessoas preparadas para falar com eles e falar deles aos outros. A mãe de santo emprega sua força na feitura da noviça e da Bamburucema da noviça, conduzindo-as em uma trajetória de formação conjunta; neste percurso distingue e responde também ao apelo de Kayala. Esta cobra reconhecimento da noviça, ameaça arruinar sua feitura, mas abre-se para a possibilidade de existência que a mãe de santo lhe oferece: aceita ser segunda.

Um pai de santo escolhe, por respeito à tradição em que foi criado ou por medo de não dominar os procedimentos rituais da feitura, não fazer um santo que pertença a uma nação diferente da nação de sua casa. Mas, ao ser lembrado que muito possivelmente o orixá já realizou sua escolha, ele hesita: talvez termine cedendo. Aprende que no candomblé os circuitos da ação envolvem a participação de muitos, que ninguém é permanentemente excluído destes circuitos, mas também que ninguém figura sozinho como autor. Aprende que no candomblé é preciso dar satisfação àqueles que têm vínculos com a casa - e que isso implica uma ética de composição.

A ebomi entra em conflito com a mãe de santo quanto à escolha do novo ocupante de um cargo de prestígio no terreiro. O Ogun da ebomi entra no conflito e dá oportunidade à mãe de santo de olhar a situação a partir da perspectiva que ele instaura, de ver com ele. A etiqueta não só potencializa essa possibilidade, como convida os participantes da situação a vivê-la intensamente.

Em cada um dos casos, a ética não diz respeito simplesmente à atribuição de valor a um mundo já pronto. É inseparável do processo mesmo de feitura dos seres e do mundo. 


\section{Notas}

${ }^{1}$ O conceito, proposto por Barry (2004) e retomado por Fraser (2006), acentua o fato de que a ética nunca é o resultado de atos exclusivamente humanos, depende de arranjos materiais, formas de organização do espaço e das interações que asseguram aos atores certas possibilidades de agir eticamente.

${ }^{2}$ As nações correspondem a tradições rituais que remontam à influência dos diferentes grupos étnicos responsáveis pela formação e consolidação do candomblé. Na Bahia, as principais nações são keto, angola e jeje.

${ }^{3}$ As divindades do candomblé são conhecidas como orixás no keto, bakisse (plural de nkisi ou inquice) no angola e voduns no jeje. São comumente chamadas de santos, principalmente quando se quer ressaltar a relação pessoal que se estabelece entre o fiel e a divindade.

${ }^{4}$ Nos candomblés de nação angola, os noviços (homens ou mulheres) são chamados de muzenza (equivalente à iaô, na nação keto). De sua feitura (iniciação) até o cumprimento da obrigação ritual que marca os sete anos da feitura, o filho de santo é muzenza. Quando "paga” a obrigação de sete anos, torna-se kota (ebomi, no keto) - adepto sênior do terreiro.

${ }^{5}$ Idade aqui é contada pelos anos de iniciação, marcados pela realização das obrigações rituais.

${ }^{6}$ Os orixás existem em múltiplos planos: em um plano geral são divindades - forças ligadas à natureza e a certas atividades humanas e relacionadas a um vasto corpus mítico; em um plano individual, são manifestações únicas dessas forças gerais, que acompanham os indivíduos humanos (ver Bastide, 2001; Goldman, 1987, 2005). A feitura faz nascer a pessoa e o seu orixá individual, manifestação única e insubstituível do orixá geral, a quem está ligada.

7 Tempo, neste caso, medido pela realização das obrigações que seguem a feitura propriamente dita, ritos que marcam principalmente três e sete anos de feitura.

${ }^{8}$ Orixás de herança são orixás que acompanham uma família e que são transmitidos por ocasião da morte de um indivíduo para algum de seus descendentes.

${ }^{9}$ Eguns são espíritos de mortos.

${ }^{10}$ Em uma passagem instigante, Bastide observa que antes que um comportamento padronizado e definido por direitos e deveres, o status social no candomblé "é a imagem do lugar ocupado pelo indivíduo na escala da existência" (2001: 228).

${ }^{11}$ Embora o termo nação se refira preponderantemente à procedência ou origem da casa, também é usado para falar da procedência da divindade (e apesar das pessoas traçarem correspondências entre orixás, bakisse e voduns, algumas divindades são tidas como exclusivas a uma ou outra nação).

${ }^{12}$ Vale notar que frequentemente essas duas definições se reforçam.

${ }^{13}$ Ogãs são adeptos masculinos que não passam pela experiência da possessão. Alguns ogãs assumem a função de tocar os atabaques durante as cerimônias.

${ }^{14}$ Essa associação entre um agir apoiado na tecnologia e a responsabilidade foi proposta por Stengers (2005a).

${ }^{15}$ A própria tradição (keto) da casa de sua mãe de santo, a que se apega Edson para justificar sua recusa de fazer um santo angola, comporta, ela mesma, adições deste tipo (muitas certamente já esquecidas enquanto adições).

${ }^{16}$ Observação feita por Ricardo Aragão em conversa com a autora. Em sua dissertação de mestrado, Aragão (2012) mostra a operação do que estou chamando de ética de composição na história de um terreiro angola de Salvador. 


\section{Referências bibliográficas}

Aragão, Ricardo

2012 Ser rodante é ser-com-outros: a possessão como experiência de alteridade num candomblé de Salvador. Salvador, dissertação, UFBA.

BARrY, Andrew

2004 “Ethical Capitalism”. In Larner, W. e Walters, W. (orgs.), Global Governmentality. Londres, Routledge.

\section{Bastide, Roger}

1973 "Le Príncipe de individuation (contribuition à une philosophie africaine)". In La Notion de personne em Afrique Noire. Colloques Internationaux du Centre National de la Recherche Scientifique, 544. Paris, Éditions du CNRS.

[1958] 2001 O Candomblé da Babia. São Paulo, Companhia da Letras.

DEWEY, John

[1908] 1980 “Teoria da Vida Moral”. In Dewey. Coleção Os Pensadores. São Paulo, Abril Cultural.

Fraser, Mariam

2006 "The Ethics of Reality and Virtual Reality: Latour, Facts and Values". History of the Human Sciences, v. 19, n. 2: 45-72.

Goldman, Márcio

1987 “A construção ritual da pessoa: a possessão no Candomblé”. In MourA, C. E. M. (org.), Candomblé: desvendando identidades. São Paulo, EMw.

2005 "Formas do saber e modos do ser: multiplicidade e ontologia no candomblé".

Religião e Sociedade. Rio de Janeiro, v. 25, n. 2: 102-120.

LAIDLAW, James

2010 "Agency and Responsibility: Perhaps You Can Have too much of a Good Thing”. In LambeK, M. (org.), Ordinary Ethics: Anthropology, Language and Action. Nova York, Fordham University Press.

2014 The Subject of Virtue: an Anthropology of Ethics and Freedom. Cambridge, Cambridge University Press. 
LAMBEK, Michael

2010a "Introduction". In (org.), Ordinary Ethics: Anthropology, Language and Action. Nova York, Fordham University Press.

2010b "Toward an ethics of the act". In . (org.), Ordinary Ethics: Anthropology, Language and Action. Nova York, Fordham University Press.

Latour, Bruno

2012 Enquête sur les modes d'existence. Paris, Éditions La Découverte.

PAPPAS, Gregory

2008 John Dewey's Ethics: Democracy as Experience. Bloomington, Indiana University Press.

PRANDI, Reginaldo

1991 Os candomblés de São Paulo: a velha magia na metrópole nova. São Paulo, Hucitec.

RabeLo, Miriam

2014 Enredos, feituras e modos de cuidado: dimensões da vida e da convivência no candomblé. Salvador, Edufba.

SOURIAU, Étienne

1943 Les Différents modes d'existence. Paris, Puf.

STENGERS, Isabelle

2005a "Introductory Notes on an Ecology of Practices". Cultural Studies Review, v.11, n.1: 183-196.

2005b “The Cosmopolitical Proposal”. In Latour, B. e Weibel, P. (orgs.), Making Things Public: Atmospheres of Democracy. Cambridge, MA, MIT Press. 


\title{
Notes on the Ethics of Candomblé
}

\begin{abstract}
The paper describes events that took place in candomblé houses of Salvador, Bahia, in order to reflect on the candomblés particular form of posing and solving ethical problems, of forming adepts' ethical sensibility and offering conditions for its exercise in the everyday life of the religious community. Approaching situations involving the initiation and gradual formation of adepts and their relations with deities, it aims to highlight elements that define ethical practice in the candomble and the ethical assemblage that sustains such practice.
\end{abstract}

KEYWORDS: Ethical Practice, Candomblé, Feitura, Relations Between Humans and Orixás.

Recebido em março de 2016. Aceito em julho de 2016. 